\title{
Mineral Excretion during Acute, Dehydrating Diarrhea Treated with Oral Rehydration Therapy
}

\author{
MANUEL RUZ ${ }^{1}$ AND NOEL W. SOLOMONS \\ Division of Nutrition and Health, Institute of Nutrition of Central America and Panama (INCAP), and the Center \\ for Studies of Sensory Impairment, Aging and Metabolism, Guatemala City, Guatemala, Central America
}

\begin{abstract}
Twenty-four male Guatemalan children, aged 7 to $23 \mathrm{mo}$, suffering dehydration due to acute diarrhea were studied to assess their fecal endogenous losses of trace minerals zinc, iron, and copper while treated with oral rehydration therapy, either with standard or glycineadded solutions. Sodium and potassium excretions (from endogenous and exogenous sources) were also monitored. No statistically significant effect of glycine was observed on any of the minerals studied, although a tendency to higher output was seen with zinc. Median rates of fecal excretion of zinc, iron, and copper were $6.08,6.33$, and $1.61 \mu \mathrm{g} / \mathrm{kg} / \mathrm{h}$, respectively, whereas those for sodium and potassium were 11.2 and $9.7 \mathrm{mg} / \mathrm{kg} / \mathrm{h}$. All of the minerals excretion showed significant linear correlations with fecal volume, $r$ values were $0.47(\mathrm{Zn}), 0.64(\mathrm{Fe}), 0.77(\mathrm{Cu}), 0.98$ $(\mathrm{Na})$, and $0.97(\mathrm{~K})$. Mineral-mineral interactions also were evident, with such correlations in fecal excretion rates as: $\mathrm{Zn}$ versus $\mathrm{Cu}, r=0.75 ; \mathrm{Zn}$ versus $\mathrm{Fe}, r=0.62 ; \mathrm{Fe}$ versus $\mathrm{Cu}, r=0.76$. (Pediatr Res 27: 170-175, 1990)
\end{abstract}

\section{Abbreviations}

ORT, oral rehydration therapy

IGSS, Institute of Social Security

Infectious diarrheal disease has long been a major cause of childhood morbidity and mortality $(1,2)$. With the advent of effective ORT $(3,4)$, exploiting the sodium-coupled absorption mechanism for glucose (5), the management of the dehydration associated with diarrhea has improved, and mortality can be dramatically reduced (6). Mata (7) showed that recurrent infectious episodes can produce growth failure and malnutrition. Thus, with the increasing survival of young children from their episodes of acute diarrhea, there is interest in the maintenance of normal nutritional status in the aftermath of infections $(8,9)$.

Interest in the trace element nutrients in relation to the child populations of the developing world has been advancing in the last decade. Due to their respective roles in nutritional anemias, endemic goiter, and cretinism, iron and iodine have long been a nutritional concern in less developed countries. In the past decade, however, interest in other trace elements such as zinc (10-12), copper (13-15), and selenium (16), in relation to Latin American child populations, has been advancing. Episodes of

Received August 31, 1987; accepted October 10, 1989.

Correspondence and reprint requests Noel W. Solomons, CeSSIAM, Hospital de Ojos y Oidos "Dr Rodolfo Robles V.", Diagonal 21 y 19 calle, zona 11, Guatemala City, Guatemala, Central America.

Supported by the United Nations University.

' Visiting investigator from the University of Chile on a fellowship from the United Nations University. Present address Department of Family Studies, University of Guelph, Guelph, Ontario, Canada N1G 2W1. diarrhea interfere with human nutriture in various ways $(17,18)$, including the provocation of excessive wasting of endogenous stores. Regarding the trace elements, our quantitative knowledge of the magnitude of nutritional loss that can result from acute diarrheal disease is minimal.

Among countries of the Third World, Guatemala has traditionally had a high incidence of diarrheal illness (7, 19). Moreover, Guatemala leads countries in tropical Latin America for the highest percentage of children less than $6 \mathrm{y}$ of age with wtfor-age less than $75 \%$ of the international standards (20). In theory, a previously deteriorated nutritional status may make a child more vulnerable to more drastic further nutritional insult from diarrheal episodes; alternatively, a state of adaptation to conserve nutrients by the malnourished child might help to spare their endogenous reserves during bouts of gastroenteritis.

Another nutritional issue is the rapidity of repletion of electrolytes and water in the dehydrated child. Based on the principle that both glucose and neutral amino acids (such as glycine) stimulate the active absorption of sodium in a potentially additive manner (5), a variant of the traditional ORT solution, containing $111 \mathrm{mmol}$ of glycine has been advanced and tested as a so-called "super ORT" $(21,22)$. We have combined the variable of glucose alone, or with glycine, as a contrast in our study.

Thus, we have undertaken the quantitative assessment of the excretion of the nutritionally important trace elements-zinc, iron, and copper-from endogenous sources in 24 male children with acute, dehydrating diarrhea, isolating the effect of glycine from the variant composition of oral rehydration solution. The excretion of both endogenous and exogenous electrolytes-sodium and potassium - was also monitored. Our results emphasize the interaction between and among the distinct, nutritional minerals.

\section{MATERIALS AND METHODS}

Subjects. We enrolled 24 male subjects aged 7 to 23 mo admitted to the Rehydration Unit of the Pediatrics Department of the General Hospital of the Guatemalan Institute of Social Security (IGSS) in Guatemala, between June and November of 1986. Males were chosen to assure effective separation of urine from contamination of fecal specimens.

The children presented with typical histories of acute, infectious diarrhea leading to dehydration, and were prescribed oral rehydration therapy as their initial treatment after evaluation by the resident on duty. Children were included if they had no more than $4 \mathrm{~d}$ of illness, if no oral medication had been given during the prior 24-h period, if no oral intake of any kind had been given during the previous $10 \mathrm{~h}$, and if no overt dysenteric stools were present. Abundant vomiting that precluded fluid therapy either by mouth or gastric feeding tube was a reason for exclusion. Except for the assignment of the type of oral rehydration formula, all aspects of medical management were handled by the duty pediatric resident. 
The protocol had been approved by the Human Subjects Committee of the Institute of Nutrition of Central America and Panama and the Research Committee of the Department of Pediatrics of IGSS. Subjects were enrolled after the nature, purpose, risks, and options of the procedures had been explained and written informed consent had been obtained from the parent or accompanying guardian.

Assignment of treatment. Once enrolled, the children were assigned at random by binary choice to receive either the standard therapy or the glycine-containing special solution. For both oral solutions the basic constituents were identical and included the ORT formula recommended by the World Health Organization (23). This contains, in mmol/L of final volume: sodium, 90; potassium, 20; bicarbonate, 30; chloride, 80; and glucose, 110. In the special formula, an additional $111 \mathrm{mmol}$ of glycine (USP, Mallinckrodt, Paris, KY) were added.

Anthropometric measurements. The observation period for each subject was defined as the interval from the moment of admission to the Rehydration Service to the time when he first was given food, beverage, or medication other than the assigned ORT formula, or when he was declared a failure with oral therapy and admitted as an inpatient for intravenous rehydration therapy. In fact, the child was followed, when possible, for the duration of his stay at the facility until he was declared fully rehydrated by the medical staff, and discharged to his home.

The subjects were weighed without clothing on a calibrated pediatric balance (SECA, Hamburg, Germany), accurate to the $10 \mathrm{~g}$, on admission, after the observation period, and at full hydrational recovery. At the conclusion of the observation period, the length of the subject was determined in the supine, recumbent position on a table stadiometer to the nearest $0.1 \mathrm{~cm}$. At this same time, the triceps skinfold thickness and mid-arm circumference were measured on the right upper extremity as suggested by Jelliffe (24). Using the method of Frisancho (25), the mid-arm muscle and fat areas, both in $\mathrm{mm}^{2}$ and as a percentage of the entire cross-sectional area, were computed. Using the wt at full hydration, when available, the adequacy of wt-for-age (26), ht-for-age (27), and wt-for-ht (27) were calculated as a percent of conventional standards (20). It should be noted that in three children, two of those who proved to be treatment failures and in one who responded to ORT but left the Rehydration Unit prematurely, no determination of the final, rehydrated wt was available.

Assessment of initial hydration state. On admission, the resident on duty made a clinical assessment of hydration status based on criteria suggested by the World Health Organization (23), mild and moderate degrees of dehydration were eligible for a trial of oral therapy by the norms of the hospital. In those 21 children in whom the wt after full rehydration recovery could be obtained, a retrospective calculation of the initial degrees of dehydration, expressed as the wt-deficit as a percent of final wt, was calculated.

Fecal collection procedures. The children were placed in a metabolic bed, and a plastic, adherent urine culture bag was placed on the perineum to separate urine. The stools were collected in clear-plastic bag liners placed inside the collection basins. Each evacuation was collected, labeled, and stored as a separate entity.

The first oral dose of ORT solution contained $20 \mathrm{mg}$ of brilliant blue (Mallinckrodt) as a fecal marker. Only the values of mineral content, excretion rates, and fecal hydration for the stools occurring with and after the first appearance of the marker in the feces were included in our subsequent laboratory determinations. The interval from the moment of administering the brilliant blue marker until its first appearance in the feces has been defined as the mouth-to-anus transit time of the oral dose.

Laboratory procedures. After measuring the individual fecal samples to the nearest $0.1 \mathrm{~mL}$, they were transferred to tracemineral-free screw-top flasks, and frozen until later chemical analysis. Subsequently, upon thawing and homogenization, an aliquot of each sample was taken, weighed on an analytical balance (Mettler Instrument Co, Hightown, NJ), and then dried at 60 to $70^{\circ} \mathrm{C}$ to a constant wt (28), to provide an estimate of the water content of that defecation. Another weighed aliquot was digested at $90^{\circ} \mathrm{C}$ with ultrapure, concentrated nitric acid (J. T. Baker Chemical Co., Phillipsburg, NJ). Hydrogen peroxide was added in a dropwise fashion as needed to assure a clear digestate. The digestate then was diluted with double-distilled water and measurements of concentrations for the minerals of interest were made by atomic absorption spectrophotometry on a Varian AA 775 instrument (Varian Techtron PTY, Ltd. Springvale, Australia) with a lamp of the appropriate energy (29). The wavelength conditions used for the respective minerals were: zinc, $213.9 \mathrm{~nm}$; copper, $324.7 \mathrm{~nm}$; iron, $248.3 \mathrm{~nm}$; sodium, $589.0 \mathrm{~nm}$; and potassium, $766.5 \mathrm{~nm}$. Recovery results for the minerals studied were: zinc, $99.7 \%$; copper, $100.4 \%$; iron, $99.0 \%$; sodium $100.6 \%$; and potassium $99.2 \%$.

In addition to the stools, mineral contents of samples of the oral rehydration solution, the glycine powder and the brilliant blue were measured by atomic absorption spectrophotometry.

Data analysis. Descriptive statistics including mean, SD, median, and range, were calculated for the variables both as global figures and by individual treatment groups. The KolmogorovSmirnov test was applied to determine the normality of distribution of the sets of variables (30). Intergroup comparisons of the means were effected using the Student's $t$-test when the conditions of normality of distribution and homogeneity of variance were met. When these were not met, the nonparametric Mann-Whitney test was used. The degree of association between variables in the same subjects was evaluated by calculating the Pearson or Spearman correlation coefficients, depending upon the distribution. Other nonlinear regression models were used to determine the "goodness of fit." All calculations were effected on a Hewlett Packard Model HP-3000 series 30 (Hewlett Packard, Cupertino, CA) using the Statistical Package for the Social Sciences software (31). In general, we considered a result to be statistically significant when the probability of an $\alpha$-error was less than $5 \%$.

\section{RESULTS}

Patients' nutritional status. The findings regarding nutritional status for the two treatment groups are presented in Table 1 . The randomization process provided groups that did not differ with regard to age, ht, wt, or any other anthropometric index. The group treated with ORT-GLY was $25 \%$ more dehydrated on admission than the ORT-GLU group, but this tendency was not statistically significant.

Overall, the degree of initial dehydration as assessed by recovery of wt with successful treatment, was $4.4 \pm 2.6 \%$ (median $3.9 \%$ ). Fifteen children had mild dehydration, i.e. $<5 \%$ wt deficit, and six moderate dehydration, i.e. 6 to $10 \%$ wt deficit.

The acute dehydration in the population was superimposed on a substantial degree of protein-energy malnutrition. Ten of 21 recovered subjects $(48 \%)$ had a wt-for-age below $75 \%$ of standard, i.e. grades II or III on the Gomez classification (26). Nine of 24 patients $(37.5 \%)$ had a deficit in ht-for-age (27), i.e. $<95 \%$ of the NCHS standards (20). Sixteen of 21 children $(76 \%)$ had some degree of acute malnutrition (27), i.e. $<90 \%$ of wt-for ht. Similarly, the mean adequacy of mid-arm muscle and fat areas, respectively, was $78.7 \pm 11.5$ and $56.2 \pm 19.0 \%$. Once again, the degree of undernutrition was equally distributed between treatment groups.

Intestinal function during $O R T$. The observation times for our subjects ranged from 240 to 535 min (mean $383 \pm 77 \mathrm{~min}$; median $380 \mathrm{~min}$ ). The observation times did not differ between treatment groups. The characteristics of intestinal function during ORT are shown by treatment groups in Table 2 . The number of stools produced during observation ranged from 3 to 24 with a mean of $10.8 \pm 6.0$ and a median of 9.5 . Mouth-to-anus transit time ranged from 20 to $242 \mathrm{~min}$, with a global median of 115 


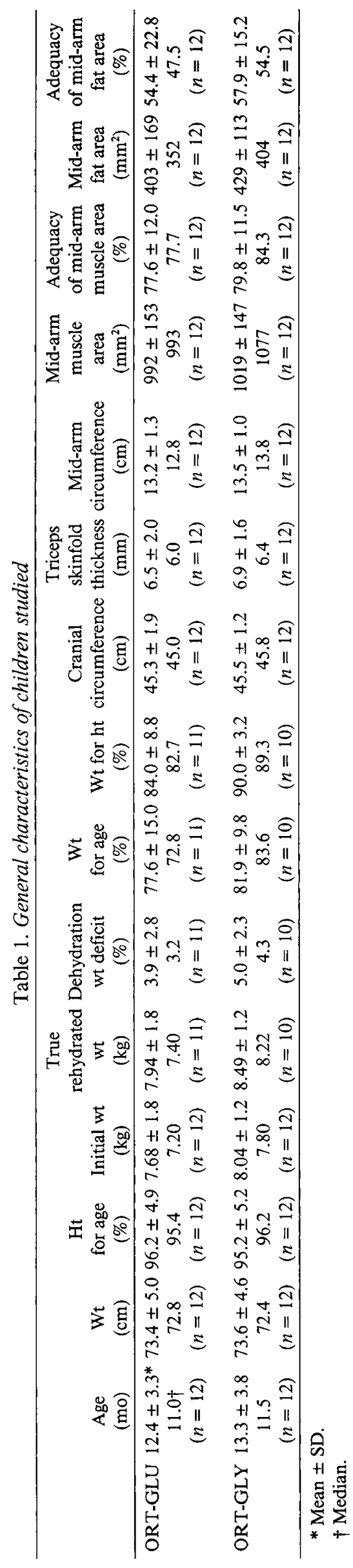

min. The content of water in the stools was $94.1 \%$ or more in all patients, and was not affected by the choice of treatment. Fecal volume excretion rates ranged from 1.0 to $50.1 \mathrm{~mL} / \mathrm{kg} / \mathrm{h}$, with an overall median of $7.5 \mathrm{~mL} / \mathrm{kg} / \mathrm{h}$. The treatment groups were comparable in their patterns of fecal fluid excretion.

Mineral content of ORT fluids. Table 3 provides the analyses of the minerals of interest in the constituents of oral intake. The single, initial dose of brilliant blue contained negligible amounts of zinc, copper, and potassium. All of the minerals, including sodium, were present at trace or undetectable levels in the glycine powder added to each liter of the special ORT. In the basic oral solution, trace metals ranged in concentration from 8.4 to 12.5 $\mu \mathrm{g} / \mathrm{L}$. There were $1970 \mathrm{mg}$ of sodium per liter in an aliquot of ORT solution as analyzed. This corresponds to $86.5 \mathrm{mmol} / \mathrm{L}$ measured, as compared to a theoretical content of $90 \mathrm{mmol} / \mathrm{L}$. A liter of ORT contained $786 \mathrm{mg}(20.4 \mathrm{mmol})$ of potassium per liter, as compared to the specified content of $20 \mathrm{mmol} / \mathrm{L}$.

Fecal excretion of trace metals. The global excretion rate for zinc was $8.10 \pm 5.74 \mu \mathrm{g} / \mathrm{kg} / \mathrm{h}$ with a median of $6.08 \mu \mathrm{g} / \mathrm{kg} / \mathrm{h}$. As shown in Table 4, there was a tendency toward a greater excretion of zinc with the ORT-GLY treatment as compared to the ORTGLU, but the difference of the means had a probability of $p=$ 0.17 , not meeting our criterion for statistical significance. The overall concentration of zinc in stools averaged $1.11 \pm 0.96 \mathrm{mg} /$ $\mathrm{L}$ with a median of $0.76 \mathrm{mg} / \mathrm{L}$. Again, there was a tendency toward a greater zinc concentration in stools of the ORT-GLY group (Table 4), but this also did not achieve statistical significance.

The global excretion rates for iron and copper for the entire 24 patients was $9.91 \pm 7.88$ and $1.92 \pm 1.04 \mu \mathrm{g} / \mathrm{kg} / \mathrm{h}$, respectively. The respective medians were 6.33 and $1.65 \mu \mathrm{g} / \mathrm{kg} / \mathrm{h}$, respectively. As shown in Table 4 , no difference between treatment groups was observed. The concentration of iron and copper in the stools of all 24 children averaged $1.16 \pm 0.93$ (median: 0.77 ) and $0.25 \pm 0.20$ (median: 0.17 ) $\mathrm{mg} / \mathrm{L}$, respectively. No intergroup differences were observed (Table 4).

Fecal excretion of electrolytes. The electrolytes in the stools were derived both from endogenous losses and the malabsorption of exogenous electrolytes in the ORT solutions. The excretion rates for sodium and potassium in all 24 children averaged 19.0 \pm 21.1 (median 11.1), and $12.9 \pm 10.1$ (median 9.7 ) $\mathrm{mg} / \mathrm{kg} / \mathrm{h}$. As shown in Table 5, there was no significant difference between the means of the two treatment groups, although the median excretion values for both electrolytes were slightly higher in the ORT-GLY group. The average concentration of the respective electrolytes was $1.28 \pm 0.38$ (median 1.32), and $1.20 \pm 0.56$ (median 1.12) g/L. As shown in Table 5 no statistically significant differences were seen across treatment groups.

Biologic interactions. Simple correlation coefficients were calculated for our fecal outcome variables, and various patient characteristics such as age, degree of dehydration, rehydrated wt, wt-for-age, wt-for ht, ht-for-age, mid-arm muscle area, mid-arm fat area, and, solely in the case of fecal volume output, number of evacuations per hour. No statistically significant correlations were found between the excretion rates for zinc, iron, or copper, and any of the patient characteristics listed. Age correlated significantly $(p<0.05)$ with the fecal concentration of all three metals. Moreover, there was a significant correlation $(r=0.51$, $p<0.05$ ) of fecal concentration of iron and ht-for-age. Inasmuch as the distribution of fecal total volume output was not normal when taken over the whole observation period $(p<0.05$ by the test of Kolmogorov-Smirnov), the Spearman correlation coefficient was used with the listed patient characteristics; only the number evacuations per $\mathrm{h}$ correlated with fecal output in $\mathrm{mL} /$ $\mathrm{kg} / \mathrm{h}(r=0.83 ; p<0.01)$.

The fecal output rates after the appearance of the fecal marker proved to be normally distributed across the population, so we used simple linear regression (Pearson's product moment) to determine the association with excretion rates of the trace metals. For zinc, iron, and copper, respectively, the correlation coeffi- 
TRACE MINERAL EXCRETION IN DIARRHEA

Table 2. Characteristics of intestinal function during $O R T$

\begin{tabular}{|c|c|c|c|c|c|}
\hline Group & No. of stools & $\begin{array}{l}\text { Mouth-to-anus } \\
\text { transit time } \\
(\mathrm{min})\end{array}$ & $\begin{array}{c}\text { Fecal excretion } \\
\text { rate } \\
(\mathrm{mL} / \mathrm{kg} / \mathrm{h})\end{array}$ & $\begin{array}{c}\text { Fecal-water } \\
\text { content } \\
(\%)\end{array}$ & $\begin{array}{c}\text { Total } \\
\text { observation } \\
\text { time } \\
\text { (min) }\end{array}$ \\
\hline ORT-GLU & $\begin{array}{c}10.3 \pm 6.5^{*} \\
9.0 \dagger \\
3-24 \ddagger\end{array}$ & $\begin{array}{c}120 \pm 63 \\
128 \\
33-235\end{array}$ & $\begin{array}{c}13.9 \pm 11.6 \\
9.4 \\
1.0-39.3\end{array}$ & $\begin{array}{c}97.4 \pm 1.2 \\
97.7 \\
94.1-98.8\end{array}$ & $\begin{array}{l}358 \pm 82 \\
350 \\
240-480\end{array}$ \\
\hline ORT-GLY & $\begin{array}{c}11.3 \pm 5.7 \\
10.0 \\
5-23\end{array}$ & $\begin{array}{c}111 \pm 62 \\
104 \\
30-242\end{array}$ & $\begin{array}{c}14.3 \pm 17.1 \\
6.6 \\
1.8-50.1\end{array}$ & $\begin{array}{c}97.4 \pm 1.0 \\
97.5 \\
95.4-98.5\end{array}$ & $\begin{array}{c}408 \pm 65 \\
395 \\
290-535\end{array}$ \\
\hline
\end{tabular}

$*$ Mean \pm SD.

$\dagger$ Median.

$\ddagger$ Range.

Table 3. Content of zinc, copper, iron, sodium, and potassium in brilliant blue, glycine, and oral rehydration solution

\begin{tabular}{lccccc}
\hline & $\begin{array}{c}\text { Zinc } \\
(\mu \mathrm{g})\end{array}$ & $\begin{array}{c}\text { Copper } \\
(\mu \mathrm{g})\end{array}$ & $\begin{array}{c}\text { Iron } \\
(\mu \mathrm{g})\end{array}$ & $\begin{array}{c}\text { Sodium } \\
(\mathrm{mg})\end{array}$ & $\begin{array}{c}\text { Potassium } \\
(\mathrm{mg})\end{array}$ \\
\hline Brilliant blue* & 1.1 & 1.3 & $\mathrm{ND} \dagger$ & 1.8 & 0.017 \\
Glycine & 0.8 & $\mathrm{ND}$ & $\mathrm{ND}$ & 0.02 & 0.009 \\
Oral rehydration solution§ & 8.4 & 10 & 12.5 & 1970 & 796 \\
\hline
\end{tabular}

* Content of $20 \mathrm{mg}$ of the marker.

$\dagger$ Not detectable.

$\ddagger$ Content in $111 \mathrm{mmol}$ of glycine.

$\S$ Content in $1 \mathrm{~L}$ of oral solution.

cients for the regression against fecal output rates were $r=0.47$, $r=0.64, r=0.77$. As shown in Figure 1, the correlations of the electrolytes with fecal volume were of an even higher order, with a difference in slope that reflects the different relative concentrations of sodium and potassium in the original ORT solution.

Shown in Table 6 are the hemimatrices of correlation for all five minerals, one with another. For fecal concentration, there were strong correlations between each pair of trace metals, and between sodium and potassium. The correlations of zinc and copper with potassium concentration were also of high order. In general, sodium concentration manifested a lower order correlation with the concentrations of the trace metals in stools. For excretion rates of the various minerals, the pattern is basically similar. Sodium and potassium excretion rates correlated at a level of $r=0.92$. At least for copper and iron, the correlation with sodium improves when expressed as excretion rate, relative to the correlation with concentration. Finally, when evaluated from the simultaneous intercorrelation of all three trace metals within individuals (Fig. 2), a generally strong overall mutual association could be demonstrated.

\section{DISCUSSION}

Diarrheal disease represents a major health challenge for the under-5-y-old population of the developing world $(1,2)$. ORT has provided a potent tool to reduce mortality from acute, infectious diarrhea, but many questions about the nutritional consequences have remained unresolved. Here we have evaluated the effect of typical diarrhea, treated with two forms of ORT, on five nutritionally important minerals. Three of them are trace elements, present in the human body at less than $0.01 \%$ (32). Each of these has its major role in intracellular functions, primarily as components of metalloproteins and metalloenzymes. In our study, exogenous sources of zinc, copper, and iron in oral fluids (Table 3) was so minute as not to constitute an important contribution to the fecal stream. Moreover, given the prior state of fasting, the active diarrhea, and the lavage with ORT fluid, the fecal trace metals must be considered to be primarily of endogenous origin. The two additional minerals were electrolytes, presented both within cells and in the extracellular fluids. The respective molar ratio of sodium and potassium in ORT is 9:2. Thus, fecal electrolytes in our subjects originated both in the oral solution (exogenous) and from internal reserves (endogenous).

The anthropometric profile of the children attending the IGSS Hospital with acute diarrhea reveals a high prevalence of both chronic and acute protein-energy malnutrition. A pertinent nutritional question emerges in the consideration of our data. Does the general nutritional status of the individuals influence the tendency for a greater loss (or a greater conservation) of minerals? In this regard, we found few significant associations between anthropometry and trace mineral output, suggesting that underlying protein-energy status is not a determinant of mineral losses during acute diarrhea.

Two biologic aspects of the trace metals of interest are worth discussing. First, with prolonged dietary restriction, mammals, including humans, have demonstrated the ability to conserve zinc $(33,34)$, iron $(35)$, and copper $(36,37)$ by reducing the rate of endogenous loss. Second, the major route for excretion of the endogenous excess of each of the trace metals in health to maintain usual nutritional balance is not by way of the urine, but rather into the fecal stream. In health, the physiologic mechanisms vary with each individual trace element. Zinc is excreted primarily in pancreatic secretions $(38,39)$; iron is excreted as a component of the desquamation of intestinal cells (35) and can also be wasted as a consequence of occult hemorrhage; and copper is excreted from the liver into the gut via the bile in a form that is not readily reabsorbed $(40,41)$. The excretion of both sodium and potassium is largely controlled by renal mechanisms under normal conditions of health, and only with diarrheal or emetic processes can the gastrointestinal loss of electrolytes exceed that of the kidneys.

In the context of these intrinsic similarities and differences among the normal physiologic mechanisms for the metabolism of the five minerals of interest, we can assess the convergent and divergent patterns of fecal excretion behavior observed in states of acute diarrhea and ORT administration. In none of the five instances of fecal mineral excretion did the presence or absence of glycine in the rehydration solution produce any difference. There was a tendency to a greater fecal output of zinc with the glycine-containing solution, but this fell short of statistical significance. In fact, because zinc is excreted by the pancreas, the additional stimulation of acinar secretion by the oral amino acids $(42,43)$ might contribute to this trend toward a greater endogenous zinc loss with the added glycine. The liberation of cholecystokinin-pancreozymin by amino acid passage through the duodenum would also be expected theoretically to enhance biliary secretion, but this was not reflected in any differential excretion of copper according to the use of glycine in the ORT.

The rate of excretion of fecal fluids was clearly a factor in 
Table 4. Fecal excretion rates and concentrations of trace elements

\begin{tabular}{|c|c|c|c|c|c|c|}
\hline \multirow[b]{2}{*}{ Group } & \multicolumn{2}{|c|}{ Zinc } & \multicolumn{2}{|c|}{ Iron } & \multicolumn{2}{|c|}{ Copper } \\
\hline & $\begin{array}{l}\text { Excretion } \\
(\mu \mathrm{g} / \mathrm{kg} / \mathrm{h})\end{array}$ & $\begin{array}{c}\text { Concentration } \\
(\mathrm{mg} / \mathrm{L})\end{array}$ & $\begin{array}{l}\text { Excretion } \\
(\mu \mathrm{g} / \mathrm{kg} / \mathrm{h})\end{array}$ & $\begin{array}{c}\text { Concentration } \\
(\mathrm{mg} / \mathrm{L})\end{array}$ & $\begin{array}{l}\text { Excretion } \\
(\mu \mathrm{g} / \mathrm{kg} / \mathrm{h})\end{array}$ & $\begin{array}{c}\text { Concentration } \\
(\mathrm{mg} / \mathrm{L})\end{array}$ \\
\hline ORT-GLU & $\begin{array}{c}6.55 \pm 5.59^{*} \\
5.88 \dagger\end{array}$ & $\begin{array}{c}0.85 \pm 0.75 \\
0.57\end{array}$ & $\begin{array}{c}8.96 \pm 7.63 \\
6.33\end{array}$ & $\begin{array}{c}0.90 \pm 0.61 \\
0.74\end{array}$ & $\begin{array}{c}1.79 \pm 0.95 \\
1.64\end{array}$ & $\begin{array}{c}0.20 \pm 0.13 \\
0.17\end{array}$ \\
\hline ORT-GLY & $\begin{array}{c}9.65 \pm 5.69 \\
9.40 \\
\end{array}$ & $\begin{array}{c}1.38 \pm 1.09 \\
0.91 \\
\end{array}$ & $\begin{array}{c}10.96 \pm 8.35 \\
6.82 \\
\end{array}$ & $\begin{array}{c}1.42 \pm 1.14 \\
0.83 \\
\end{array}$ & $\begin{array}{c}2.06 \pm 1.14 \\
1.88 \\
\end{array}$ & $\begin{array}{c}0.31 \pm 0.25 \\
0.17\end{array}$ \\
\hline
\end{tabular}

$\dagger$ Median.

Table 5. Fecal excretion rates of electrolytes

\begin{tabular}{ccccc}
\hline & \multicolumn{2}{c}{ Sodium } & & \multicolumn{2}{c}{ Potassium } \\
\cline { 2 - 4 } Group & $\begin{array}{c}\text { Excretion } \\
(\mathrm{mg} / \mathrm{kg} / \mathrm{h})\end{array}$ & $\begin{array}{c}\text { Concentration } \\
(\mathrm{g} / \mathrm{L})\end{array}$ & $\begin{array}{c}\text { Excretion } \\
(\mathrm{mg} / \mathrm{kg} / \mathrm{h})\end{array}$ & $\begin{array}{c}\text { Concentration } \\
(\mathrm{g} / \mathrm{L})\end{array}$ \\
\hline ORT-GLU & $\begin{array}{c}19.2 \pm 18.7^{*} \\
12.4 \dagger\end{array}$ & $1.38 \pm 0.40$ & $13.0 \pm 8.9$ & $1.08 \pm 0.28$ \\
& 1.46 & 11.6 & 1.12 \\
ORT-GLY & $18.8 \pm 24.2$ & $1.17 \pm 0.35$ & $12.7 \pm 11.7$ & $1.31 \pm 0.74$ \\
& 6.7 & 1.25 & 7.9 & 1.13 \\
\hline
\end{tabular}

$*$ Mean $\pm \mathrm{SD}$

$\dagger$ Median.

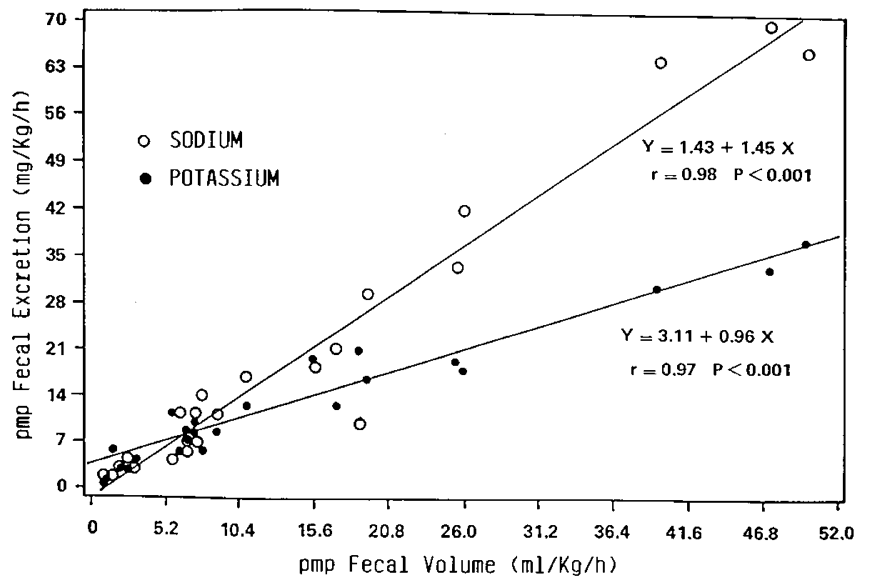

Fig. 1. The scattergram and linear regression equations for rate of fecal excretions of sodium (open circles) and potassium (closed circles) versus rate of fecal volume excretion.

determining the excretion rate of each of the individual minerals, as the correlation coefficients of mineral outputs with volume outputs range from 0.47 to 0.98 . It is not unexpected that electrolytes that are contained in fixed amounts in the ORT fluids and in relatively fixed amounts in diarrheal transudation (44) should have a strict linear relationship with changes in total fluid volume. It is of note that copper had a relationship to the rate of fluid lose with an $r$ value as high as 0.77 . Apparently, however, associated factors, other than the rate of lavage of the intestines with extrinsic and intrinsic fluids, were operating, as the linear regression for the fecal concentration or excretion rates of any two trace metals together were generally higher than the respective correlation with fecal volume. This suggests intuitively that during the diarrheal episodes, the three trace minerals were coming from a common pool within the body in which they were in some fixed relation to one another. The intravascular circulation and the epithelial cells of the gut are two possible pools that could be contributing the metals with a relatively
Table 6. Correlation matrices among fecal excretion rates and concentrations of minerals

\begin{tabular}{lcccc} 
& Copper & Iron & Sodium & Potassium \\
\hline Fecal excretion rates & & & & \\
Zinc & 0.75 & 0.62 & 0.34 & 0.53 \\
Copper & & 0.75 & 0.67 & 0.85 \\
Iron & & & 0.53 & 0.67 \\
Sodium & & & & 0.92 \\
& & & & \\
Fecal concentration & \multirow{2}{*}{0.90} & 0.71 & -0.35 & 0.67 \\
Zinc & & 0.70 & -0.45 & 0.87 \\
Copper & & & -0.37 & 0.49 \\
Iron & & & & -0.61 \\
Sodium & & & & \\
\hline
\end{tabular}

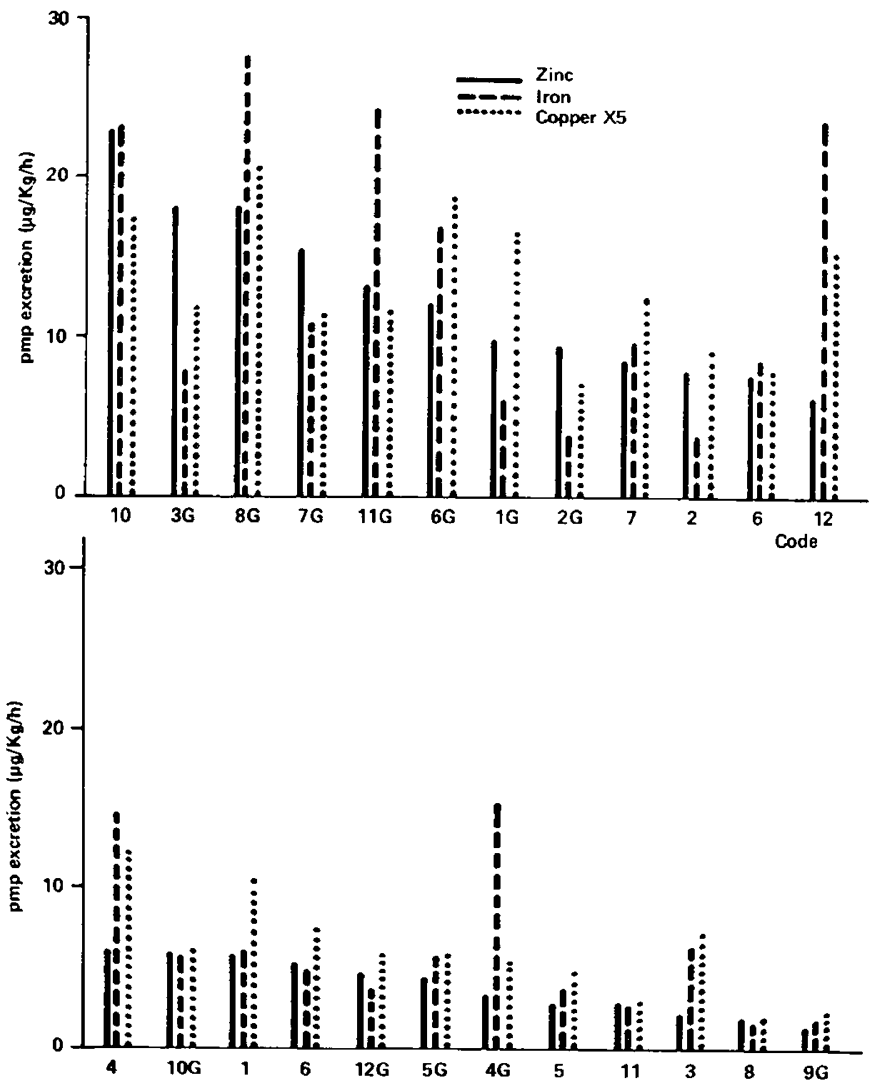

Fig. 2. The individuals in the series are ranked in descending order of their individuals rates of fecal excretion of zinc. Shown along side each solid zinc excretion bar is the interrupted bar representing iron excretion rates and the dotted bar representing copper excretion rates $(\times 5)$. 
stable intermineral ratio. The intracellular concentration of intestinal cells is not known but the ratio of zinc:iron:copper of approximately 5:5:1 (Fig. 2), is not dissimilar from the dietary pattern. If enterocytes retained untransferred trace metals in roughly the proportions to which they were exposed to them from the lumen, the mucosal epithelium would represent a strong candidate as the "common source."

However, a similar argument can be made with respect to the plasma if the loosely bound fractions are considered. The relative concentrations of zinc, iron, and copper in the circulation is about unity. However, both the zinc on its albumin carrier and the iron on its transferrin carrier are easily removed, and only about $10 \%$ of circulating copper is not firmly incorporated in ceruloplasmin (45). Thus, if the loosely bound plasma trace metals were appearing in the fecal stream by transudation, a similar pattern of zinc and iron in equivalent amounts, and copper in reduced amounts, would be expected. Thus, strong arguments for the derived pattern coming from either desquamated epithelial cells of the gut or transudation of plasma are both logically sustainable. Without further experimentation, no rational means to decide between these two options is presented.

The ratio of sodium to potassium in the oral fluid is $9: 2$, but this is modified to approximately $2: 1$ in the fecal excretion. Unlike the trace metals, which are not represented in oral intake, sodium, potassium, and water have a potential for bidirectional flux, i.e. from body-to-lumen and from lumen-to-body. The fact of successful rehydration in 21 of 24 patients is testimony to a net accumulation in the body of water and sodium. The final resultant fecal electrolyte concentration is most likely the result of a differentially greater extraction of water and sodium, than potassium, from the ORT fluids.

Given the enduring importance of diarrhea as a public health problem for the children of the developing world and given the emerging importance of trace metal nutrition as a topic in the Third World, it was timely to quantitate the degree of losses of zinc, iron, and copper from the body stores during episodes of infectious gastroenteritis. Three trace metals with some overlapping, but some vastly different metabolic properties, seem to behave similarly within individuals regarding relative endogenous losses. The biologic bases for this excretory association during diarrhea and ORT treatment are not yet clarified.

Acknowledgments. The authors express their appreciation to the pediatric house-officers and nursing staff of the Outpatient Rehydration Unit of the Guatemalan Institute for Social Security Pediatric Hospital, and specifically Gladys Arriola. We are also grateful for the technical assistance in the analysis of trace elements of Dr. Oscar Pineda, Silvia Morales, and Estela Juarez.

\section{REFERENCES}

1. Rhode JE, Northrup RS 1976 Taking science where the diarrhea is. In: Acute Diarrhea in Childhood. Ciba Foundation Symposium 42: Elsevier, Excerpta Medica, New York, pp 339-366

2. Hirschhorn N 1980 The treatment of acute diarrhea in children: an historical and physiological perspective. Am J Clin Nutr 33:637-663

3. Mahalanabis D, Merson M, Barua D 1981 Oral rehydration therapy: Recent advances. World Health Forum 2:245-249

4. Santosham M, Daum RS, Dillman L, Rodriguez J, Luque S, Russell R, Kourany M, Beneson AS, Sack RB 1982 Oral rehydration therapy of infantile diarrhea: a controlled study of well-nourished children hospitalized in the United States and Panama. N Engl J Med 306:1071-1076

5. Nalin DR Cash RA, Rahman M, Yunus MD 1970 Effect of glycine and glucose on sodium and water absorption in patients with cholera. Gut 11:768-772

6. Pape J, Mondestin B, Jasmin L, Kean BH, Rohde JE, Johnson WD. 1983. management of diarrhea in Haiti: mortality reduction in 8445 hospitalized children. In: Cash R, McLaughlin J (eds) Proceedings of the International Congress on Oral Rehydration Therapy. Agency for International Development. Washington, D.C

7. Mata LS 1978 The Children of Santa Maria Cauque. Prospective Field Study or Health and Growth. M.I.T. Press, Cambridge, MA

8. National Research Council 1985 Nutritional Management of Acute Diarrhea in Infants and Children. National Academy Press, Washington, DC

Walker-Smith JA 1986 Nutritional management of acute gastroenteritis-rehy- dration and realimentation. Hum Nutr Appl Nutr 40(suppl 1):39-43

10. Golden BE, Golden MNH 1981 Plasma zinc, rate of weight gain, and the energy cost of tissue deposition in children recovering from severe malnutrition on a cow's milk or soy protein-based diet. Am J Clin Nutr 34:892-898

11. Golden MHN, Golden BE 1981 Effect of zinc supplementation on dietary intake rate of weight gain and energy cost of tissue deposition in children recovering from severe malnutrition. Am J Clin Nutr 34:900-908

12. Ruz M, Vera G, Araya H 1985 Calidad nutricional de la dieta con respecto a zinc y su relacion con la ingeta diaria en preescolares chilenos. Rev Chil Nutr 13:13-18

13. Uauy R, Castillo-Duran C, Fisberg M, Fernandez N, Valenzuela A 1985 Red cell Superoxide-dismutase activity in nutritional copper deficiency. J Nutr 115:1650-1658

14. Cordano A, Baertl JM, Graham GC 1964 Copper deficiency in infancy. Pediatrics 34:324-336

15. Castillo-Duran C, Fisberg M, Valenzuela A, Egana JI, Uauy R 1983 Controlled trial of copper supplementation during recovery from marasmus. Am Clin Nutr 37:898-903

16. Solomons NW, Torun B, Janghorbani M, Christensen MJ, Young VR, Steinke FH. 1986 Absorption of selenium from milk-protein and isolated-soy-protein formulas in preschool children: studies using a stable isotope tracer. J Pediatr formulas in preschool childre

17. Rosenberg IH, Solomons NW, Schneider RE 1977 Malabsorption associated with diarrhea in intestinal infections. Am J Clin Nutr 30:1248-1253

18. Keusch GT, Solomons NW 1985 Microorganisms, malabsorption, diarrhea and dysnutrition. In: Calabrese EJ, Scherr GH (eds) Advances in Human Nutrition, Vol 2. Chem-Orbital, Park Forest, IL pp 165-209

19. Scrimshaw NS, Taylor CE, Gordon GE 1968 Interactions of Nutrition and infection. WHO Monograph Series 57. WHO, Geneva

20. World Health Organization 1983 Measuring changes in nutritional status. Guidelines for assessing the nutritional impact of supplementary feeding programs for vulnerable groups WHO, Geneva

21. Patra FC, Mahalanabis D, Jalan KN, Sen Banerjee P 1984 In search of a super solution: controlled trial of glycine-glucose oral rehydration solution in infantile diarrhea. Acta Paediatr Scand 73:18-21

22. Vesikari $\Upsilon$ Isolauri E 1986 Glycine supplemented oral rehydration solutions for diarrhoea. Arch Dis Chil 61:372-376

23. World Health Organization 1984 Programs for Control of Diarrhoeal Diseases. A Manual for the Treatment of Acute Diarrhoea. WHO, Geneva

24. Jelliffe DB 1966 The Assessment of the Nutritional Status of the Community. WHO Monograph Series No 53. WHO, Geneva, pp 63-78

25. Frisancho $A R \quad 1981$ New norms of upper limb fat and muscle areas for assessment of nutritional status. Am J Clin Nutr 34:2540-2545

26. Gomez F, Galvan RR, Cravioto J, Feank S 1955 Malnutrition in infancy with special reference to kwashiorkor. Adv Pediatr 7:131-169

27. Waterlow JC 1972 Classification and definition of protein-energy malnutrition. Br Med J 3:566-569

28. Caballero B 1982. Estudios metabolicos sobre calcio y nitrogeno en ninos desnutridos alimentados con leche con o sin lactosa. Masters of Science thesis, Universidad de San Carlos de Guatemala

29. Varian AA776 Series Operation Manual 1970 Atomic Absorption Spectrophotometer. Varian Techtron Pty Ltd, Spingvale, Australia

30. Daniel WW 1977 Bioestadistica. Base para el Analisis de las Ciencias de la Salud, 19th ed. Editorial Limusa, Mexico City

1. Nie NH, Hull Ch. Jenkins JG. Stennbrenner H, Bent BH 1975 Statistical Package for the Social Sciences, 2nd ed. McGraw-Hill Book Co., New York

32. Mertz W 1981 The essential trace elements. Science 213:1332-1338

33. Wiegand E, Kirchgessner M 1980 Total true efficiency of zinc utilization Determination and homeostatic dependence upon the zinc supply status in young rats. J Nutr 110:469-480

34. Prasad AS, Brewer GJ, Schoomaker EB, Rabbani P 1978 Experimental zinc deficiency in humans. Ann Intern Med 89:483-490

35. Green R, Charlton R, Seftel H, Bothwell T, Mayer F, Adams B, Finch C Layrisse M 1968 Body iron excretion in man. A collaborative study. Am J Med 45:336-353

36. Gitlin D, Hughes WL, Janeway CA 1960 Absorption and excretion of copper in mice. Nature 188:150-151

37. Owen Jr CA 1964 Absorption and excretion of ${ }^{64} \mathrm{Cu}$-labeled copper by the rat. Am J Physiol 207:1203-1206

38. Pekas UC 1966 Zinc- 65 metabolism: Gastrointestinal secretion by the pig. Am J Physiol 207:1203-1206

39. Sullivan JF Williams RV, Wisecarver J, Etzel K, Jetton MM, Magee DF 1981 The zinc content of bile and pancreatic juice in zinc-deficient swine. Proc Soc Exp Biol Med 166:39-43

40. Gollan JL, Deller DJ 1973 Studies on the nature and excretion of biliary copper in man. Clin Sci 44:9-15

41. McCullars GM, O'Reilly SO, Brennan M 1977 Pigment binding of copper in human bile. Clin Chim Acta 74:33-38

42. Hendrix TR. The secretory function of the alimentary canal. 1974. In: Mountcastle VBं (ed) Medical Physiology. CV Mosby Co, St. Louis, pp 1178-1207

43. Go VLW, Hoffman AF, Summerskill WHJ. 1970. Pancreozymin bioassay in man based on pancreatic enzyme secretion: potency of specific aminoacids and other digestive products. J Clin Invest 49:1558-1564

44. Phillips RA 1964 Water and electrolyte losses in cholera. Fed Proc 23:705-712

45. Delves HT 1976 The microdetermination of copper in plasma protein fraction. Clin Chim Acta 71:495-500 